\title{
Chemometrics - Assisted UV Spectrophotometric Method for Determination of Ciprofloxacin and Ornidazole in Pharmaceutical Formulation
}

\author{
Santosh V. Gandhi*, Abhilash D. Waghmare, Yash S. Nandwani, Amit S. Mutha \\ AISSMS College of Pharmacy, Kennedy Road, Pune- 411001, Maharashtra, India \\ santoshvgandhi@rediffmail.com
}

\begin{abstract}
This presented work is based on application of two multivariate calibration methods for simultaneous UV-Vis spectrophotometric determination of active substances in combined pharmaceutical formulation composed of Ciprofloxacin (CPX) and Ornidazole (ONZ). The methods used were Principal Component Regression (PCR) and Partial Least Square (PLS). The Spectra of both CPX and ONZ were recorded at concentrations within their linear ranges 2.0-12.0 $\mu \mathrm{g} / \mathrm{ml}$. 27 set of mixtures were used for calibration and 9 set of mixtures were used for validation in the wavelength range of 267 to $330 \mathrm{~nm}$ with the wavelengths intervals $\lambda=0.5 \mathrm{~nm}$ in methanol. International Conference on HarmonizationQ2 (RI) (ICH) guidelines were followed to validate the methods. Recovery study results indicate no interference of the excipients, thus methods were successfully applied for determination of drugs in pharmaceutical formulation. The methods can be used as alternative analytical tool in the quality control of these drugs.
\end{abstract}

Keywords:Ciprofloxacin, Ornidazole, PLS, PCR, Validation

\section{INTRODUCTION}

Ciprofloxacin (CPX) chemically 1-cyclopropyl-6-fluoro-4-oxo-7-piperazin-1-ylquinoline-3-carboxylic acid, [Fig.1 (a)] is a fluoroquinolone antibiotic used to treat a number of bacterial infections [1] Ornidazole(ONZ) chemically is 1-Chloro-3-(2-methyl-5-nitro-1H-imidazol-1-yl)propan-2ol[Fig.1(b)]. Itis aantiamoebic agent that interacts with helical DNA strand which leads in a protein synthesis inhibition and cell death[2]. Several methods are reported for quantitative determination of CPX and ONZ in single and in combination such as UV[3-6] and RP-HPLC[7-10].

a)

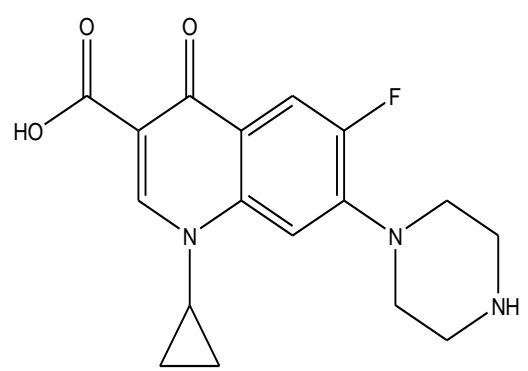

b)

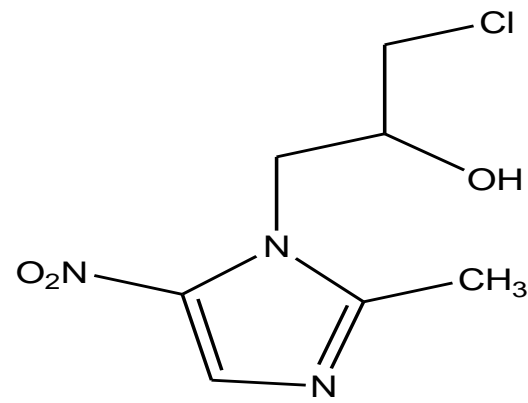

Figure1.Structure of a) Ciprofloxacin (CPX) and b) Ornidazole (ONZ)

Chemometrics was introduced in 1972 by SvanteWold [11].Chemometric is the science of extracting information from chemical system. For determination of mixtures including drugs combination; chemometric approaches like multiple linear regression (MLR), principle component regression (PCR) and partial least squares (PLS) utilizing spectrophotometric data can be used [12].As there are no reports on chemometric analysis of these drugs, this work was undertaken which presents simple, accurate and reproducible multivariate spectrophotometric methods for simultaneous determination of $\mathrm{CPX}$ and ONZ in tablet dosage form.

\section{MATERIALS AND METHODS}

\subsection{Instrumentation}

Double beam UV- Vis spectrophotometer (Jasco V-550) with matched pair of $1 \mathrm{~cm}$ quartz cells were used to record spectra of all solutions. The spectra were recorded at spectral band width of $2.0 \mathrm{~nm}$, 
scanning speed $400 \mathrm{~nm} / \mathrm{min}$ and data pitch $0.5 \mathrm{~nm}$. Unscrambler X (10.3) (64-bit) trial version and Microsoft Excel 2007 were used for model generation and application of chemometric.

\subsection{Material and Reagents}

Reference standard of CPX and ONZ were obtained from Cipla Ltd, Mumbai as gift samples and methanol used was of AR grade (LOBA Chemie, India). ZOXAN-OZ tablets manufactured by FDC Limited (Goa) containing Ciprofloxacin IP $500 \mathrm{mg}$ and Ornidazole IP $500 \mathrm{mg}$ were procured from local pharmacy shop.

\subsection{One Component Calibration}

One component calibration was studied in the concentration range of 2.0-12.0 $\mu \mathrm{g} / \mathrm{ml}$ for both CPX and ONZ. Absorbance values wererecorded at $\lambda_{\max }$ of each drug $(278 \mathrm{~nm}$ for CPX and $311 \mathrm{~nm}$ for ONZ) against methanol as blank. Linear dynamic range for each compound was determined by leastsquare linear regression of concentration and the corresponding absorbance. Fig. 2 represents overlain spectra of CPX and ONZ and their mixture.

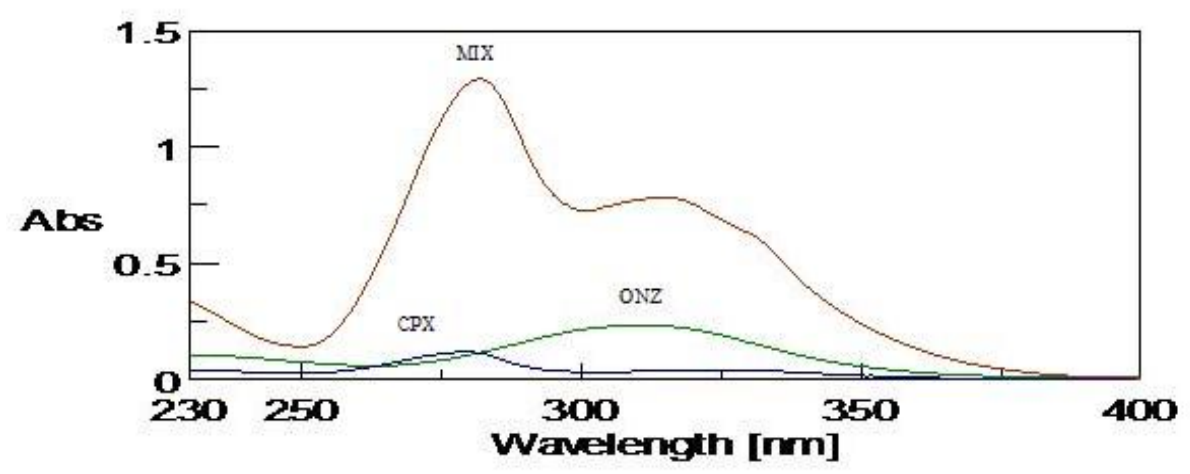

Figure2.Overlay spectra of $C P X, O N Z$ and mixture.

\subsection{Preparation of Standard Stock Solution}

Stock solution of CPX and ONZ were prepared by dissolving accurately weighed $10 \mathrm{mg}$ of standard drugs in $10 \mathrm{ml}$ of methanol, separately. The concentration of CPX and ONZ were $1000 \mu \mathrm{g} / \mathrm{ml}$ from which further $5 \mathrm{ml}$ was pipetted and diluted to $50 \mathrm{ml}$ to achieve final concentration of $100 \mu \mathrm{g} / \mathrm{ml}$ of CPX and ONZ respectively.

\subsection{Preparation of Working Stock Solution}

Working standard solutions were prepared from standard stock solution of $100 \mu \mathrm{g} / \mathrm{ml}$ by appropriate dilution with methanol to obtain final concentration of 2, 4, 6, 8, 10 and $12 \mu \mathrm{g} / \mathrm{ml}$ for both CPX and ONZ.

\subsection{Construction of Calibration and Validation Set}

By combining standard stock solution of CPX and ONZ,36 mixtures were prepared in their linear concentration range of 2.0-12.0 $\mu \mathrm{g} / \mathrm{ml}$ (Table 1). Out of 36 mixtures,randomly selected 27 mixtures wereusedfor model development (calibration set) andremaining 9 mixtures were used for model validation (validation set). The absorbance spectra were recorded in range of 267- $330 \mathrm{~nm}$ with 0.5 $\mathrm{nm}$ interval. The spectra were saved as ASCII (.txt) format which were further extracted in MS-Excel as required by Unscrambler software for model generation. The PCR and PLS models were developed utilizing absorption data using Unscrambler software. Selection of proper number of latent variables for development of model was necessary to obtain good prediction. Leave-one-out (LOO) cross validation method was used to obtain necessary number of latent variables (LVs), as shown in Figure 3 and calculated using formula [13],

MSECV $=\sqrt{\sum \frac{(\text { Cact }- \text { Cpre })^{2}}{I c}}$

Where,

RMSECV $=$ Root mean square error of cross validation

Cact $=$ actual concentration of calibration set

Cpre $=$ predicted concentration of validation set

$\mathrm{Ic}=$ Total number of samples in calibration set 
Chemometrics-Assisted UV Spectrophotometric Method for Determination of Ciprofloxacin and Ornidazole in Pharmaceutical Formulation

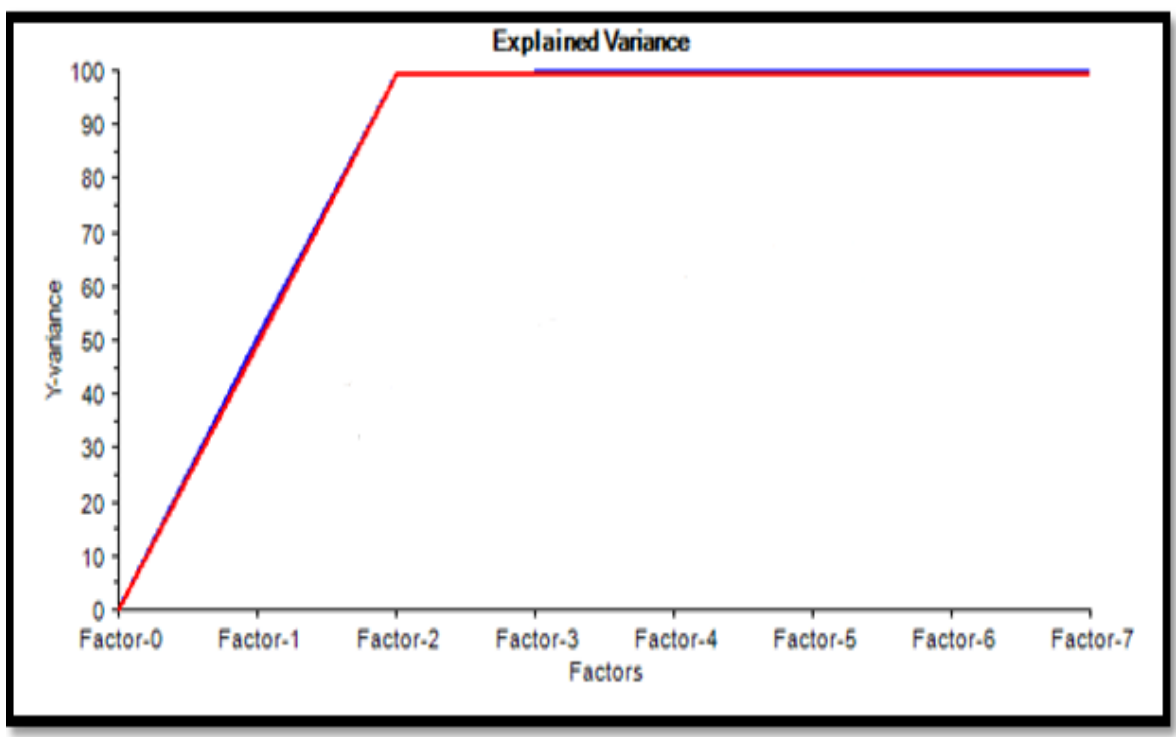

Figure3.Explained variance describing number of optimum PCs (Principle Components).

After the PCR and PLS models have been constructed, it was found that the optimum number of LVs were two factors for both PCR and PLS. For validation of generated models, concentration in validation set was predicted by using proposed PCR and PLS models (Table 2). The validation of allmethods was performed as per ICH Q2 (R1) [14].

Table1.Composition of calibration and validation sets. ${ }^{*}$ Mix no. 1-27 calibration set; *Mix no. 28-36 validation set.

\begin{tabular}{|l|l|l|l|l|l|}
\hline MIX. NO & $\mathbf{O N Z}(\boldsymbol{\mu g} / \mathbf{m l})$ & $\mathbf{C P X}(\boldsymbol{\mu g} / \mathbf{m l})$ & $\mathbf{M I X . N O}$ & $\mathbf{O N Z}(\boldsymbol{\mu g} / \mathbf{m l})$ & $\mathbf{C P X}(\boldsymbol{\mu g} / \mathbf{m l})$ \\
\hline 1 & 2 & 2 & 19 & 12 & 8 \\
\hline 2 & 4 & 2 & 20 & 2 & 10 \\
\hline 3 & 6 & 2 & 21 & 6 & 10 \\
\hline 4 & 10 & 2 & 22 & 8 & 10 \\
\hline 5 & 12 & 2 & 23 & 12 & 10 \\
\hline 6 & 2 & 4 & 24 & 2 & 12 \\
\hline 7 & 4 & 4 & 25 & 6 & 12 \\
\hline 8 & 8 & 4 & 26 & 10 & 12 \\
\hline 9 & 10 & 4 & 27 & 12 & 12 \\
\hline 10 & 2 & 6 & 28 & 8 & 2 \\
\hline 11 & 4 & 6 & 29 & 6 & 4 \\
\hline 12 & 8 & 6 & 30 & 12 & 4 \\
\hline 13 & 10 & 6 & 31 & 6 & 6 \\
\hline 14 & 12 & 6 & 32 & 6 & 8 \\
\hline 15 & 2 & 8 & 33 & 4 & 10 \\
\hline 16 & 4 & 8 & 34 & 10 & 10 \\
\hline 17 & 8 & 8 & 35 & 4 & 12 \\
\hline 18 & 10 & 8 & 36 & 8 & 12 \\
\hline
\end{tabular}

Table2. Predicted results for validation set by PCR and PLS method.

\begin{tabular}{|c|c|c|c|c|c|c|c|c|c|}
\hline \multicolumn{2}{|c|}{ METHOD } & \multicolumn{4}{|c|}{ PLS } & \multicolumn{4}{|c|}{ PCR } \\
\hline$C P X$ & ONZ & \multicolumn{2}{|l|}{$C P X$} & \multicolumn{2}{|l|}{ ONZ } & \multicolumn{2}{|l|}{$C P X$} & \multicolumn{2}{|l|}{ ONZ } \\
\hline \multicolumn{2}{|c|}{ Actual $(\mu \mathrm{g} / \mathrm{ml})$} & Predicted & $\% \mathrm{R}^{*}$ & Predicted & $\% \mathbf{R}^{*}$ & Predicted & $\% R^{*}$ & Predicted & $\% \mathrm{R}^{*}$ \\
\hline 2 & 8 & 2.071 & 103.5 & 8.186 & 102.3 & 2.071 & 103.5 & 8.186 & 102.3 \\
\hline 4 & 6 & 3.829 & 95.74 & 6.171 & 102.8 & 3.829 & 95.72 & 6.171 & 102.8 \\
\hline 4 & 12 & 3.95 & 98.17 & 12.31 & 102.6 & 3.951 & 98.79 & 12.39 & 102.61 \\
\hline 6 & 6 & 5.353 & 89.22 & 5.841 & 97.35 & 5.352 & 89.2 & 5.842 & 97.37 \\
\hline 8 & 6 & 7.538 & 94.23 & 6.069 & 101.1 & 7.537 & 94.22 & 6.07 & 101.1 \\
\hline 10 & 4 & 9.932 & 99.32 & 4.054 & 101.3 & 9.932 & 99.22 & 4.054 & 101.3 \\
\hline 10 & 10 & 9.194 & 91.94 & 9.542 & 95.42 & 9.193 & 91.93 & 9.542 & 95.42 \\
\hline 12 & 4 & 11.822 & 98.51 & 3.974 & 99.29 & 11.822 & 98.52 & 3.971 & 99.28 \\
\hline 12 & 8 & 12.026 & 100.2 & 7.602 & 95.03 & 12.027 & 100.2 & 7.6 & 95.01 \\
\hline
\end{tabular}




\subsection{Assay of Marketed Preparation}

20 tablets of ZOXAN-OZ were accurately weighed and finely powdered. Tablet powder equivalent to $10 \mathrm{mg}$ of CPX (10 mg of ONZ) was taken and transferred to $10 \mathrm{ml}$ volumetric flask and was diluted to $10 \mathrm{ml}$ with methanol. The solution was sonicated for 10 minutes. This solution was filtered and 1 $\mathrm{ml}$ of filtrate was diluted to $10 \mathrm{ml}$ with methanol. Further $0.4 \mathrm{ml}$ of this solution was diluted to $10 \mathrm{ml}$ with methanol to get final concentration of $4 \mu \mathrm{g} / \mathrm{ml}$ of both CPX and ONZ. The procedure was repeated 6 times for tablet formulation. The results of assay are presented in Table3.

Table3.Assay result for $C P X$ and $O N Z$ in tablet (ZOXAN-OZ) by proposed methods.

\begin{tabular}{|c|c|c|c|c|c|c|c|c|c|}
\hline \multicolumn{2}{|c|}{ METHOD } & \multicolumn{4}{|c|}{ PLS } & \multicolumn{4}{|c|}{ PCR } \\
\hline$C P X$ & ONZ & \multicolumn{2}{|c|}{$C P X$} & \multicolumn{2}{|c|}{ ONZ } & \multicolumn{2}{|c|}{$C P X$} & \multicolumn{2}{|c|}{ ONZ } \\
\hline \multicolumn{2}{|c|}{$\operatorname{Actual}(\mu \mathrm{g} / \mathrm{ml})$} & $\begin{array}{l}\text { Predicted } \\
(\mu \mathrm{g} / \mathrm{ml})\end{array}$ & $\% \mathbf{R}$ & $\begin{array}{l}\text { Predicted } \\
(\mu \mathrm{g} / \mathrm{ml})\end{array}$ & $\% \mathbf{R}$ & $\begin{array}{l}\text { Predicted } \\
(\mu \mathrm{g} / \mathrm{ml})\end{array}$ & $\% \mathbf{R}$ & $\begin{array}{l}\text { Predicted } \\
(\mu \mathrm{g} / \mathrm{ml})\end{array}$ & $\% \mathbf{R}$ \\
\hline 4 & 4 & 4.1372 & 103.4 & 4.1493 & 103.7 & 4.1325 & 103.3 & 4.1496 & 103.7 \\
\hline 4 & 4 & 4.0184 & 100.4 & 4.0411 & 101.0 & 4.0137 & 100.3 & 4.0416 & 101.0 \\
\hline 4 & 4 & 4.1234 & 103.0 & 4.0011 & 100.0 & 4.1248 & 103.1 & 4.0013 & 100.0 \\
\hline 4 & 4 & 3.9872 & 99.68 & 4.1542 & 103.8 & 3.9885 & 99.71 & 4.1543 & 103.8 \\
\hline 4 & 4 & 4.1284 & 103.2 & 3.9912 & 99.78 & 4.1267 & 103.1 & 3.9945 & 99.86 \\
\hline 4 & 4 & 4.1032 & 102.5 & 4.0541 & 101.3 & 4.1024 & 102.5 & 4.0542 & 101.3 \\
\hline \multicolumn{2}{|c|}{ MEAN } & 4.0829 & 102.0 & 4.0651 & 101.6 & 4.0812 & 102.0 & 4.0659 & 101.6 \\
\hline \multicolumn{2}{|c|}{ SD } & 0.0638 & 1.596 & 0.0711 & 1.777 & 0.0636 & 1.559 & 0.0704 & 1.732 \\
\hline
\end{tabular}

\subsection{Accuracy study}

The accuracy study was carried out at three levels $50 \%, 100 \%$ and $150 \%$ of assay concentration. Calculated amount of CPX and ONZfrom standard solutionswere spiked into sample solution and scanned in range of 267-330 nm. Concentrations were predicted by using developed PCR and PLS models. Accuracy data is presented in Table 4 and Table 5.

Table4. Accuracy data of CPX by PCR and PLS models.

\begin{tabular}{|c|c|c|c|c|c|c|c|c|c|}
\hline $\begin{array}{l}\text { LEVEL } \\
\%\end{array}$ & $\begin{array}{l}\text { Sample } \\
\text { Conc. } \\
\mu \mathrm{g} / \mathrm{ml}\end{array}$ & $\begin{array}{l}\text { Amount } \\
\text { added } \\
\mu \mathrm{g} / \mathrm{ml}\end{array}$ & $\begin{array}{l}\text { Total } \\
\text { Conc. } \\
\mu \mathrm{g} / \mathrm{ml}\end{array}$ & \multicolumn{2}{|c|}{$\begin{array}{l}\text { Predicted } \\
\text { Conc. } \\
\mu \mathrm{g} / \mathrm{ml}\end{array}$} & \multicolumn{2}{|c|}{ \% Recovery } & \multicolumn{2}{|c|}{$\%$ RSD } \\
\hline & & & & PCR & PLS & PCR & PLS & PCR & PLS \\
\hline $50 \%$ & 4 & 2 & 6 & $\begin{array}{l}6.187 \\
6.024 \\
6.155 \\
\end{array}$ & $\begin{array}{l}6.187 \\
6.023 \\
6.165 \\
\end{array}$ & $\begin{array}{l}103.13 \\
100.41 \\
102.59 \\
\end{array}$ & $\begin{array}{l}103.13 \\
100.39 \\
102.75 \\
\end{array}$ & 1.409 & 1.456 \\
\hline $100 \%$ & 4 & 4 & 8 & $\begin{array}{l}7.942 \\
8.054 \\
8.012 \\
\end{array}$ & $\begin{array}{l}7.942 \\
8.053 \\
8.013 \\
\end{array}$ & $\begin{array}{l}99.27 \\
100.67 \\
100.15\end{array}$ & $\begin{array}{l}99.27 \\
100.67 \\
100.16 \\
\end{array}$ & 0.708 & 0.706 \\
\hline $150 \%$ & 4 & 6 & 10 & $\begin{array}{l}9.974 \\
9.994 \\
10.243\end{array}$ & $\begin{array}{l}9.984 \\
9.972 \\
10.23\end{array}$ & $\begin{array}{l}99.74 \\
99.94 \\
102.43\end{array}$ & $\begin{array}{l}99.84 \\
99.72 \\
102.33\end{array}$ & 1.488 & 1.463 \\
\hline
\end{tabular}

Table5.Accuracy data of ONZ by PCR and PLS models.

\begin{tabular}{|c|c|c|c|c|c|c|c|c|c|}
\hline $\begin{array}{l}\text { Level } \\
\%\end{array}$ & $\begin{array}{l}\text { Sample } \\
\text { Conc. } \\
\mu \mathrm{g} / \mathrm{ml}\end{array}$ & $\begin{array}{l}\text { Amount } \\
\text { added } \\
\mu \mathrm{g} / \mathrm{ml}\end{array}$ & $\begin{array}{l}\text { Total } \\
\text { Conc. } \mu \mathrm{g} / \mathrm{ml}\end{array}$ & \multicolumn{2}{|c|}{$\begin{array}{l}\text { Predicted } \\
\text { Conc. } \mu \mathrm{g} / \mathrm{ml}\end{array}$} & \multicolumn{2}{|c|}{ \% Recovery } & \multicolumn{2}{|c|}{$\%$ RSD } \\
\hline & & & & PCR & PLS & PCR & PLS & PCR & PLS \\
\hline $50 \%$ & 4 & 2 & 6 & $\begin{array}{l}6.223 \\
6.225 \\
6.102\end{array}$ & $\begin{array}{l}6.222 \\
6.224 \\
6.101\end{array}$ & $\begin{array}{l}103.71 \\
103.75 \\
101.71\end{array}$ & $\begin{array}{l}103.76 \\
103.73 \\
101.68\end{array}$ & 1.139 & 1.148 \\
\hline $100 \%$ & 4 & 4 & 8 & $\begin{array}{l}7.973 \\
8.053 \\
8.169\end{array}$ & $\begin{array}{l}7.971 \\
8.054 \\
8.175\end{array}$ & $\begin{array}{l}99.63 \\
100.63 \\
102.11\end{array}$ & $\begin{array}{l}99.63 \\
100.67 \\
102.18\end{array}$ & 1.235 & 1.222 \\
\hline $150 \%$ & 4 & 6 & 10 & $\begin{array}{l}10.223 \\
10.255 \\
10.437\end{array}$ & $\begin{array}{l}10.221 \\
10.256 \\
10.438\end{array}$ & $\begin{array}{l}102.23 \\
102.55 \\
104.37\end{array}$ & $\begin{array}{l}102.21 \\
102.56 \\
104.38\end{array}$ & 1.120 & 1.130 \\
\hline
\end{tabular}

\subsection{Precision}

Precision was carried at three concentration levels $(4,6,8 \mu \mathrm{g} / \mathrm{ml}$ of both CPX and ONZ) in three replicates at each level. The results of which are presented in Table6 and Table7. 
Chemometrics-Assisted UV Spectrophotometric Method for Determination of Ciprofloxacin and Ornidazole in Pharmaceutical Formulation

Table6.Precision results obtained using developed PCR and PLS models (Intraday precision).

\begin{tabular}{|c|c|c|c|c|c|c|c|c|c|c|c|c|c|}
\hline \multicolumn{2}{|c|}{$\begin{array}{l}\text { Amount } \\
\text { Taken } \\
\mu \mathrm{g} / \mathrm{ml}\end{array}$} & \multicolumn{4}{|c|}{$\begin{array}{c}\text { Predicted } \\
\text { Conc. } \\
\mu \mathrm{g} / \mathrm{ml}\end{array}$} & \multicolumn{4}{|c|}{ \% Recovery } & \multicolumn{4}{|c|}{ \% RSD } \\
\hline \multirow[b]{2}{*}{ ONZ } & \multirow[b]{2}{*}{$C P X$} & \multicolumn{2}{|c|}{$\overline{\text { PCR }}$} & \multicolumn{2}{|c|}{ PLS } & \multicolumn{2}{|c|}{ PCR } & \multicolumn{2}{|c|}{ PLS } & \multicolumn{2}{|c|}{ PCR } & \multicolumn{2}{|c|}{ PLS } \\
\hline & & ONZ & $C P X$ & ONZ & $C P X$ & ONZ & $C P X$ & ONZ & $C P X$ & ONZ & $C P X$ & ONZ & $C P$ \\
\hline 4 & 4 & 4.100 & 3.956 & 4.100 & 3.956 & 102.5 & 98.90 & 102.5 & 98.9 & & & & \\
\hline 4 & 4 & 4.088 & 3.964 & 4.087 & 3.964 & 102.2 & 99.10 & 102.1 & 99.10 & 1.321 & 0.119 & 1.318 & 0.120 \\
\hline 4 & 4 & 4.001 & 3.964 & 4.002 & 3.964 & 100.0 & 99.10 & 100.0 & 99.10 & & & & \\
\hline 6 & 6 & 6.021 & 6.006 & 6.021 & 6.006 & 100.3 & 100.1 & 100.3 & 100.1 & & & & \\
\hline 6 & 6 & 6.159 & 6.118 & 6.159 & 6.187 & 102.6 & 103.1 & 102.6 & 103.1 & 1.371 & 1.502 & 1.370 & 1.496 \\
\hline 6 & 6 & 6.173 & 6.118 & 6.173 & 6.118 & 102.8 & 101.9 & 102.8 & 101.9 & & & & \\
\hline 8 & 8 & 8.124 & 8.141 & 8.124 & 8.141 & 101.5 & 101.7 & 101.5 & 101.7 & & & & \\
\hline 8 & 8 & 7.957 & 8.002 & 7.958 & 8.002 & 99.46 & 100.0 & 99.47 & 100.0 & 1.121 & 1.205 & 1.122 & 1.208 \\
\hline 8 & 8 & 7.984 & 7.955 & 7.985 & 7.955 & 99.80 & 99.44 & 99.80 & 99.44 & & & & \\
\hline
\end{tabular}

Table7.Precision results obtained using developed PCR and PLS models (Interday Precision).

\begin{tabular}{|c|c|c|c|c|c|c|c|c|c|c|c|c|c|}
\hline \multicolumn{2}{|c|}{$\begin{array}{c}\text { Amount } \\
\text { Taken } \\
\mu \mathrm{g} / \mathrm{ml}\end{array}$} & \multicolumn{4}{|c|}{$\begin{array}{l}\text { Predicted } \\
\text { Conc. } \\
\mu \mathrm{g} / \mathrm{ml}\end{array}$} & \multicolumn{4}{|c|}{ \% Recovery } & \multicolumn{4}{|c|}{ \% RSD } \\
\hline \multirow{2}{*}{$\begin{array}{l}\text { ONZ } \\
4\end{array}$} & & \multicolumn{2}{|c|}{$\begin{array}{c}\text { PCR } \\
\text { ONZCPX }\end{array}$} & \multicolumn{2}{|c|}{$\begin{array}{c}\text { PLS } \\
\text { ONZ CPX }\end{array}$} & \multicolumn{2}{|c|}{ PCR } & \multicolumn{2}{|c|}{$\begin{array}{c}\text { PLS } \\
\text { ONZCPX }\end{array}$} & \multicolumn{2}{|c|}{$\begin{array}{c}\text { PCR } \\
\text { ONZCPX }\end{array}$} & \multicolumn{2}{|c|}{$\begin{array}{c}\text { PLS } \\
\text { ONZCPX }\end{array}$} \\
\hline & & 3.98 & 3.99 & 3.98 & 3.99 & 99.53 & \begin{tabular}{|l}
99.87 \\
\end{tabular} & 99.51 & 99.8 & & & & \\
\hline 4 & 4 & 4.02 & 4.11 & 4.02 & 4.11 & 100.7 & 102.7 & 100.7 & 102.7 & 1.649 & 1.643 & 1.674 & 1.628 \\
\hline 4 & 4 & 4.16 & 3.99 & 4.16 & 3.99 & 104.1 & 99.92 & 104.1 & 99.95 & & & & \\
\hline 6 & 6 & 6.13 & 5.90 & 6.13 & 5.90 & 102.2 & 98.44 & 102.2 & 98.46 & & & & \\
\hline 6 & 6 & 6.25 & 5.98 & 6.25 & 5.98 & 104.3 & 99.81 & 104.3 & 99.80 & 1.468 & 1.691 & 1.473 & 1.685 \\
\hline 6 & 6 & 6.08 & 6.10 & 6.08 & 6.10 & 101.3 & 101.8 & 101.3 & 101.8 & & & & \\
\hline 8 & 8 & 7.90 & 7.95 & 7.90 & 7.94 & 98.85 & 99.41 & 98.86 & 99.2 & & & & \\
\hline 8 & 8 & 8.05 & 8.11 & 8.05 & 8.10 & 100.6 & 101.4 & 100.6 & 101.4 & 1.772 & 1.349 & 1.777 & 1.352 \\
\hline 8 & 8 & 8.25 & 8.15 & 8.25 & 8.15 & 103.2 & 101.9 & 103.2 & 101.8 & & & & \\
\hline
\end{tabular}

\subsection{LOD and LOQ}

LOD (Limit of detection) and LOQ (Limit of quantitation) were calculated using the formula $3.3 \mathrm{\sigma} / \mathrm{S}$ and $10 \sigma / \mathrm{S}$, respectively; where $\sigma$ is the standard deviation (y-intercept) and $\mathrm{S}$ is the slope of the calibration plot.

\section{RESULTS}

Out of 36 mixtures, 27 set of mixtures were used for calibration and 9 set of mixtures were used for validation. The models were tried to develop with varying $\Delta \lambda$. The best results were obtained with the wavelengths intervals $\lambda=0.5 \mathrm{~nm}$ in methanol. The developed method found to be accurate as results are close to $100 \%$ and precise with \% RSD less than 2. Summary of results is presented in Table 8.

Table8.Summary of results.

\begin{tabular}{|l|l|l|l|l|}
\hline Parameters & \multicolumn{2}{|c|}{ CIPROFLOXACIN(CPX) } & \multicolumn{2}{c|}{ ORNIDAZOLE (ONZ) } \\
\hline & PCR & PLS & PCR & PLS \\
\hline Range $(\mu \mathrm{g} / \mathrm{ml})$ & $2.0-12.0$ & $2.0-12.0$ & $2.0-12.0$ & $2.0-12.0$ \\
\hline Wavelength $(\mathrm{nm})$ & $267-330$ & $267-330$ & $267-330$ & $267-330$ \\
\hline Data interval $(\Delta \lambda)$ & 0.5 & 0.5 & 0.5 & 0.5 \\
\hline Factors / PC's & 2 & 2 & 2 & 2 \\
\hline$\%$ Recovery & 102.0 & 102.0 & 101.6 & 101.6 \\
\hline LOD & 0.53 & 0.53 & 0.49 & 0.49 \\
\hline LOQ & 1.52 & 1.52 & 1.49 & 1.49 \\
\hline Correlation Coefficient $\left(\mathrm{r}^{2}\right)$ & 0.9893 & 0.9894 & 0.9949 & 0.9949 \\
\hline Intercept & 0.0723 & 0.0722 & 0.0350 & 0.0351 \\
\hline Slope & 0.9893 & 0.9894 & 0.9949 & 0.9949 \\
\hline RMSECV & 0.3470 & 0.3395 & 0.26024 & 0.26032 \\
\hline RMSEP & 0.3469 & 0.3465 & 0.26023 & 0.26032 \\
\hline
\end{tabular}




\section{Conclusion}

A study of the use of UV spectrophotometric in combination with PLS and PCR for the simultaneous determination of Ciprofloxacin (CPX) and Ornidazole (ONZ) in a binary mixture has been accomplished. The results were obtained which confirmed that the proposed method is suitable for simple, accurate and precise analysis of ONZ and CPX in pharmaceutical dosage form without separation of ONZ and CPX before analysis. The above method can also be applied for analysis of drugs in quality control lab as well as for in process quality control.

\section{ACKNOWLEDGMENT}

Authors are thankful to the Principal, AISSMS college of Pharmacy for providing necessary facilities to carry out the experiment. Authors are also thankful to Cipla Pharmaceuticals Ltd, Mumbai for providing a Reference standard of Ciprofloxacin and Ornidazole.

\section{REFERENCES}

[1] http://www.drugbank.ca/drugs/DB00537 (accessed on 24.02. 2017).

[2] http://www.genericpedia.com/generic/ornidazole/(accessed on 24.02. 2017).

[3] Grewal A. S., Patro S. K., Kanungo S. K. and Bhardwaj S. K., Simultaneous Spectrophotometric Estimation of Ciprofloxacin and Ornidazole in Tablet dosage Form, International Journal of Pharmaceutical Sciences and Research July 2012. Vol. 3(8): P -2716-2720.

[4] Natarj K. S., Surnrna Y., Prasanti G. and Saikumar S. V., UV Spectrophotometric Method Development and Validation of Simultaneous Estimation of Ciprofloxacin and Ornidazole in Tablet Dosage Form, International Research Journal of Pharmacy 2013 4(7) P: 178-181.

[5] Patel S. A., Patel N. M., and Patel M. M., Simultaneous Spectroscopic Estimation of Ciprofloxacin and Ornidazole in Tablet Indian Journal of Pharmaceutical Sciences, 2006, Vol. 68 Issue 5, P: 665-667.

[6] Ramya Krishna J., Naga Sandhya B., HuidromSanayaima, Prasad V. V. L. N, Development And Validation of UV Spectrophotometric Method For The Simultaneous Estimation of Ciprofloxacin Hydrochloride And Ornidazole In Combined Pharmaceutical Dosage Form, Journal of Advanced Pharmacy Education \& Research Oct-Dec 2014 Vol 4 Issue 4 P 405-408.

[7] Ramya Krishna J., Naga Sandhya B., HuidromSanayaima, Prasad V. V. L. N, Development and Validation of RP-HPLC method for the Simultaneous estimation of Ciprofloxacin Hydrochloride and Ornidazole in Combined Pharmaceutical Dosage Form Journal of Advanced Pharmacy Education \& Research Oct-Dec 2014 Vol 4 Issue 4, P: 810-813.

[8] Nimila I. Carolin, Balan P, Sundar R. Sathiya, Kumar J. Ashok, Rajasekar S., Simultaneous RPHPLC Estimation Of Ciprofloxacin Hydrochloride And Ornidazole In Tablet Dosage Form Asian Journal Of Research In Chemistry Year:2011,Volume:4, Issue 2P :227- 230

[9] Shah Rohit, MagdumChandrakant, Patil S. K., Reverse phase HPLC method for simultaneous estimation of ciprofloxacin and Ornidazole in tablet dosage form, Indian Drugs, September 200845(9) P: 726-730.

[10] Patel Satish A, Development And Validation of RP-HPLC Method For Simultaneous Determination Of Ciprofloxacin And Ornidazole In Tablets, International Journal of Current Pharmaceutical Research Vol 3, Issue 4, 2011 P: 72-75.

[11] Sarrafi A, Konoz E, Feyzbakhsh A., Chemometrics -Assisted simultaneous determination of atenolol and furosemide in synthetic binary mixtures and combined tablet preparations. EJournal of Chemistry 2010 (Jan) 7: 997-1002.

[12] Dinc E, Baleanu D., Spectrophotometric quantitative determination of cilazapriland hydrochlorothiazide in tablets by chemometric methods. Journal of Pharmaceutical and Biomedical Analysis 2002 (May) 30: 715-723. 
Chemometrics-Assisted UV Spectrophotometric Method for Determination of Ciprofloxacin and Ornidazole in Pharmaceutical Formulation

[13] Bhaskar R, Sagar M, Saini V, Bhat M., UV-spectrophotometric-assisted chemometric methods for the simultaneous determination of metformin hydrochloride and gliclazide in pharmaceutical formulations. Pharmaceut Anal Acta 2012 (June) 3: 1-5.

[14] International Conference on Harmonization. ICH harmonized tripartite guideline validation of analytical procedures text and methodology Q2(R1) ICH, Geneva; 2005 P.1-17.

Citation: Santosh V Gandhi et al. Chemometrics-Assisted UV Spectrophotometric Method for Determination of Ciprofloxacin and Ornidazole in Pharmaceutical Formulation. ARC Journal of Pharmaceutical Sciences. 2017;3(1):19-25.

Copyright: (C) 2017 Santosh V Gandhi et al. This is an open-access article distributed under the terms of the Creative Commons Attribution License, which permits unrestricted use, distribution, and reproduction in any medium, provided the original author and source are credited. 